\title{
An Experimental Investigation On Effect Of Openings In Rc Deep Beams
}

\author{
Abinaya $\mathrm{S}^{1}$, Manivannan. $\mathrm{M}^{2}$ \\ \{sabinaya94@gmail.com¹,mmv.civil@psgtech.ac.in $\left.{ }^{2}\right\}$ \\ ${ }^{1}$ Former Post Graduate student, ${ }^{2}$ Associate Professor, Department of Civil Engineering, \\ PSG College of Technology, Coimbatore, India
}

\begin{abstract}
Transfer beams in coastal projects and foundations, bunker walls, and loadbearing walls in buildings are all popular applications for reinforced concrete deep beams. Openings in such beams are required to enable doors and windows, as well as equipment such as ventilation ducts and air conditioning systems. The deep beams with openings would reduce its shear capacity, posing a major safety issue. Only a few investigations onbehavioral aspects and capacity of deep RC beams with openings have been published. Because such openings are unavoidable, adequate reinforcing measures must be adopted to compensate for the loss of strength. The purpose of this experiment is to investigate deep beams with various types of openings. Casting and testing of three deep beams with openings under a two-point load. The sample has a $150 \mathrm{~mm} \times 500 \mathrm{~mm}$ cross section and an overall length of $1.2 \mathrm{~m}$. There are two openings in each beam and they are symmetrically placed around the mid span of the beam, one in each shear span.The percentage decrease in the ultimate load of thelong square-opening girder is $4,032 \%$ compared to the long round-opening girder. Deep beams with square and circular openings failed due to shear and exhibited shear cracks.
\end{abstract}

Keywords: Deep Beams, Reinforced Concrete, Openings.

\section{Introduction}

Clause 29 of IS 456:2000 code of practice states that a simply supported beam with L/D less than 2 shall be classified as deep beam. RC Continuous beams shall be considered deep, if the $\mathrm{L} / \mathrm{D}$ ratio is less than 2.5 . The effective span is either 1.15 times the free span or the centre to centre distance between the supports, whichever is less. When compared to pure bending, this causes the strain distribution to be non-linear and the shear strains to be substantial. Strength of deep beam is regulated by shear rather than bending due to their proportions. Mechanical and electrical connections, as well as passageways such as door and hallway openings in structures, frequently necessitate large holes through deep beams. For window and door installations, as well as the passage of utility lines and vents, deep beam openings may be desirable. The height of the building floor can be decreased by allowing tunnels in deep beams for utility facilities.

Basil Mathew [1] proposed a methodology for constructing three-dimensional non-linear FEM (Finite Element Model). For deep beams with web holes and basalt fibre reinforced polymer (BFRP) composites externally attached. A total of sixteen finite element models were investigated. There were $180 \times 180 \mathrm{~mm}$ and $120 \times 120 \mathrm{~mm}$ square holes, as well as 
$160 \mathrm{~mm}$ and $100 \mathrm{~mm}$ diameter circular openings. The shear strength of the beam decreased as the opening size grew larger, regardless of shape.

SiewChoo Chin et al. studied the behavior of RC deep beams with large circular openings and the openings that were reinforced with externally bonded CFRP composites in shear under four point loading. A total of three beams of $35 \mathrm{MPa}$ design strength have been tested till failure.Researchers employed a deep beam withoutopening and two numbers of deep beams with enormous circular openings to evaluate the behavior of control and beams strengthened using CFRP wrap. The deep RC beam with large circular openings in the shear zone revealed a significant loss of strength while compared to the original strength of the control beam, with a reduction of 51 percent. The surface strengthening strategy could only recoup 56 percent of the beam capacity when compared to the control beam.

\section{Materials Used}

\subsection{Cement}

The concrete is made up of 53 grade Ordinary Portland Cement (OPC), The specific gravity of the cement is 3.15 .

Table1CharacteristicsofOPC 53 grade cement

\begin{tabular}{|r|l|l|}
\hline S.No & Characteristics & $\begin{array}{l}\text { Results obtained from Laboratory } \\
\text { Experiment }\end{array}$ \\
\hline 1 & Standard Consistency & 32 percentage \\
\hline 2 & Settingtime( Initial) & 345 minutes \\
\hline 3 & Setting time(Final) & 510 minutes \\
\hline
\end{tabular}

\subsection{Fine Aggregate}

According to IS 383:2016, the fine aggregate utilized was clean dry M Sand with a size of in $4.75 \mathrm{~mm}$ and a fineness modulus of 2.26 in grading zone II.

Table 2 Physical Characteristics ofM Sand

\begin{tabular}{|c|l|l|}
\hline S.No & Characteristics & $\begin{array}{l}\text { Laboratory test } \\
\text { Results }\end{array}$ \\
\hline 1 & $\begin{array}{c}\text { Specific } \\
\text { Gravity(SG) }\end{array}$ & 2.734 \\
\hline 2 & $\begin{array}{c}\text { Water } \\
\text { Absorption(WA) }\end{array}$ & $2.805 \%$ \\
\hline
\end{tabular}




\subsection{Coarse Aggregate}

The coarse aggregate conforming to $20 \mathrm{~mm}$ size category and with a fineness modulus of 7.12 wereusedfor mix design and casting.

Table3 Physical Characteristicsof Gravel (CA)

\begin{tabular}{|c|c|c|}
\hline S.No & Characteristics & $\begin{array}{l}\text { Laboratory test } \\
\text { Results }\end{array}$ \\
\hline $\mathbf{1}$ & $\begin{array}{c}\text { Specific } \\
\text { Gravity(SG) }\end{array}$ & 2.886 \\
\hline $\mathbf{2}$ & $\begin{array}{c}\text { Water } \\
\text { Absorption(WA) }\end{array}$ & $0.4 \%$ \\
\hline
\end{tabular}

\subsection{Water}

Water, the most significant component in concrete manufacturing, is employed in the precise amounts because it regulates many of the fresh and hardened concrete qualities, such as workability, compressive strength, drying shrinkage, and cracking.

\section{PROPORTION OF CONCRETE MIX}

The material requirements and mix proportion for one cubic metre of M25 Grade of concrete designed as per IS 10262:2009 is given below

Weight of Cement $\quad=383 \mathrm{~kg}$

Weight of Water $\quad=192 \mathrm{~kg}$

M Sand $\quad=713.5 \mathrm{~kg}$

Gravel $($ Coarse Aggregate $)=1229 \mathrm{~kg}$

$\mathrm{W} / \mathrm{C}$ ( Water-Cement) ratio $\quad=0.5$

Mix ratio $=0.5: 1: 1.86: 3.206$

\section{Tests On Hardened Concrete}

\subsection{Cube Compression Test}

The average of strengths of the three cubes of $150 \mathrm{~mm}$ side is considered to obtainthe 28 days strength of concrete. 
Table 4 Compressive strength test results of Cube

\begin{tabular}{|c|c|c|}
\hline Sl.No & Load (t) & $\begin{array}{l}\text { Compressive } \\
\left.\text { strength( } \mathbf{N} / \mathbf{m m}^{\mathbf{2}}\right)\end{array}$ \\
\hline 1 & 61 & 26.59 \\
\hline 2 & 62 & 27.03 \\
\hline 3 & 64 & 27.90 \\
\hline
\end{tabular}

The average compressive strength is $27.17 \mathrm{~N} / \mathrm{mm}^{2}$.

\subsection{Split-Tension Test}

The strength of three plain concrete cylindrical specimens of $150 \mathrm{~mm}$ diameter and 300 $\mathrm{mm}$ height is used to evaluate the 28-day split tensile strength of concrete.

Table 5 Split Tensile StrengthTestresults

\begin{tabular}{|c|c|c|}
\hline SI.No & Load (t) & $\begin{array}{c}\text { Split Tensile strength } \\
\left(\mathbf{N} / \mathbf{m m}^{2}\right)\end{array}$ \\
\hline 1 & 17 & 2.35 \\
\hline 2 & 15 & 2.08 \\
\hline 3 & 18 & 2.49 \\
\hline
\end{tabular}

The average split tensile strength is $2.31 \mathrm{~N} / \mathrm{mm}^{2}$.

\subsection{Modulus of Rupture (Flexural tensile strength)Test}

Three plain concrete prisms of $100 \mathrm{~mm} \times 100 \mathrm{~mm}$ section and $350 \mathrm{~mm}$ span are cast and tested to establish failure load in flexure. The flexural strength is calculated by taking the average of the strengths of the three prisms.

Table 6 Results of Flexural Strength Test

\begin{tabular}{|c|c|c|c|c|}
\hline S.NO & $\begin{array}{l}\text { Load } \\
(\mathrm{kg})\end{array}$ & a (mm) & $\begin{array}{l}\text { Flexural strength( } \\
\left.\mathrm{N} / \mathbf{m m}^{2}\right)\end{array}$ & $\begin{array}{l}\text { Average flexural } \\
\text { strength }\left(\mathrm{N} / \mathrm{mm}^{2}\right)\end{array}$ \\
\hline 1 & 1820 & 123 & 6.24 & \multirow[t]{3}{*}{6.08} \\
\hline 2 & 1770 & 136 & 6.07 & \\
\hline 3 & 1720 & 148 & 5.90 & \\
\hline
\end{tabular}

\section{Testing Of Deep Beams}

\subsection{Test specimen}


The beams are cast and have a cross section of $500 \mathrm{~mm} \times 150 \mathrm{~mm}$ and a length of $1200 \mathrm{~mm}$. Square openings sized $150 \mathrm{~mm} \times 150 \mathrm{~mm}$ and round openingssized $150 \mathrm{~mm}$ diameter are located symmetrically about the mid depth and at $225 \mathrm{~mm}$ from the mid-span of the beam. The reinforcements for the deep beams are shown below
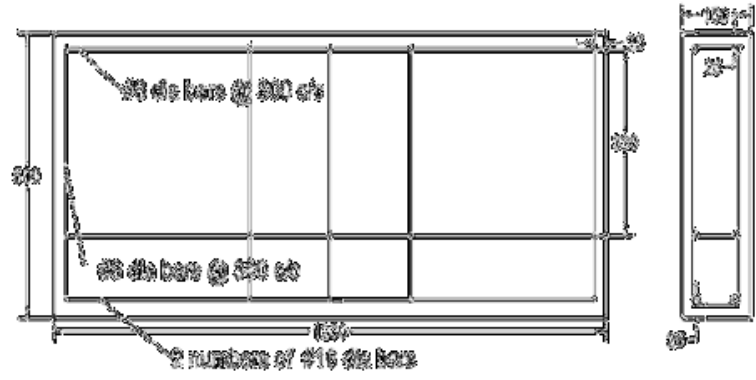

Figure1Reinforcement Detailing for Deep Beam without Opening
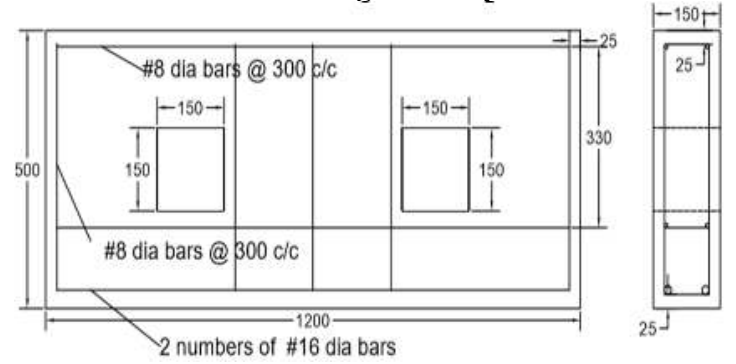

Figure 2 Reinforcement Detailing for Deep Beam with Square Openings
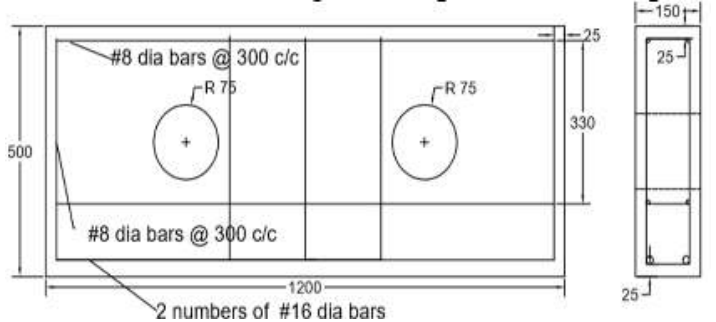

Figure 3 Reinforcement Detailing for Deep Beam with Circular Openings

\subsection{Test Set-up}

With a $1050 \mathrm{~mm}$ effective span and $350 \mathrm{~mm}$ shear span, the beams were tested under a two-point load. The two point loads were $350 \mathrm{~mm}$ apart and symmetrically spaced from the mid-span of the prism. At the bottom of the beam an LVDT (linear variable displacement transducer) is installed monitoring the deflection in the center of the span 


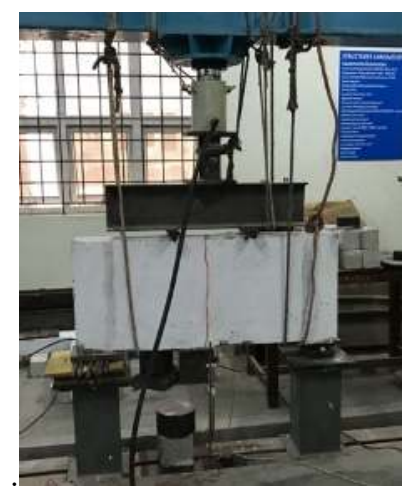

Figure 4Two Point Loading arrangement for Deep Beam without Openings



Figure 5 Two Point Loading of Deep Beam with Square Openings

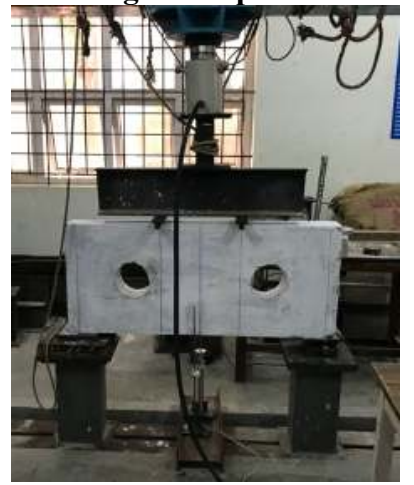

Figure 6.Two Point Loading of Deep Beam with Circular Openings

5.3 Results and Discussions

5.3.1 DeepBeam without Opening

The first crack occured at a 270 kNload with a deflection of $2.18 \mathrm{~mm}$. 


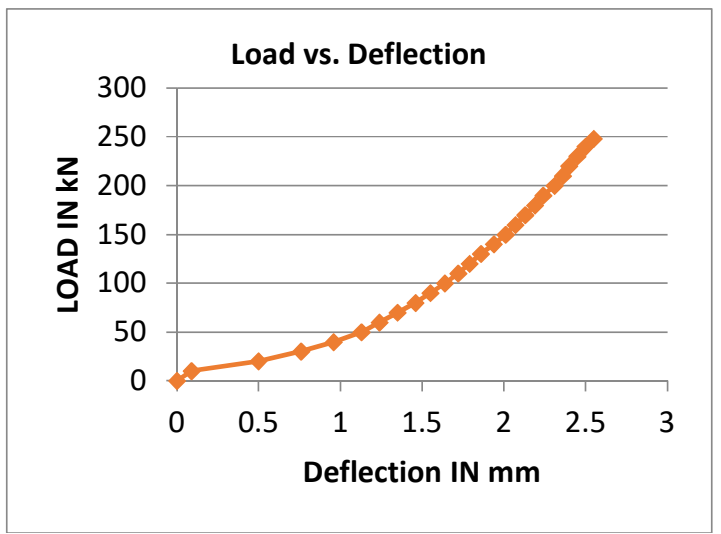

Figure 7Load Deflection Behavior of Deep Beam control specimens

\subsubsection{Deep Beam with Square Openings}

The first crack appeared under a load of $90 \mathrm{kN}$ and a $1.93 \mathrm{~mm}$ deflection. As the load continued to increase, crack propagation continued and the beam failed at $238 \mathrm{kN}$ with a maximum deflection of $5.15 \mathrm{~mm}$. The deep beam with square openings failed by shear showing shear cracks within the shear span and no flexural cracks were found.

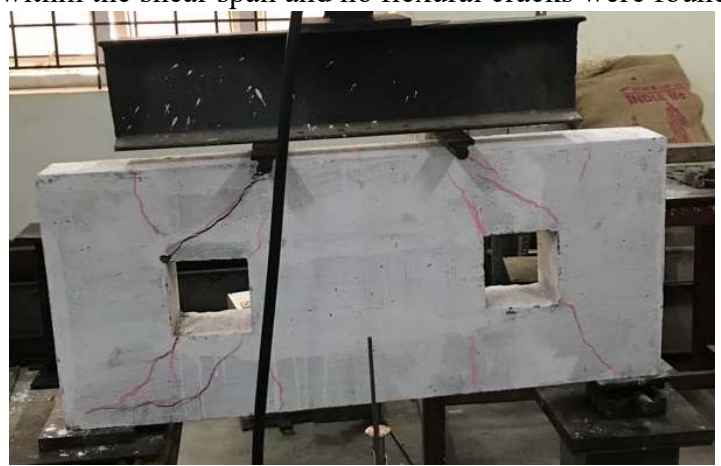

Figure 8 Crack Pattern Observed in Deep Beam with Square Openings

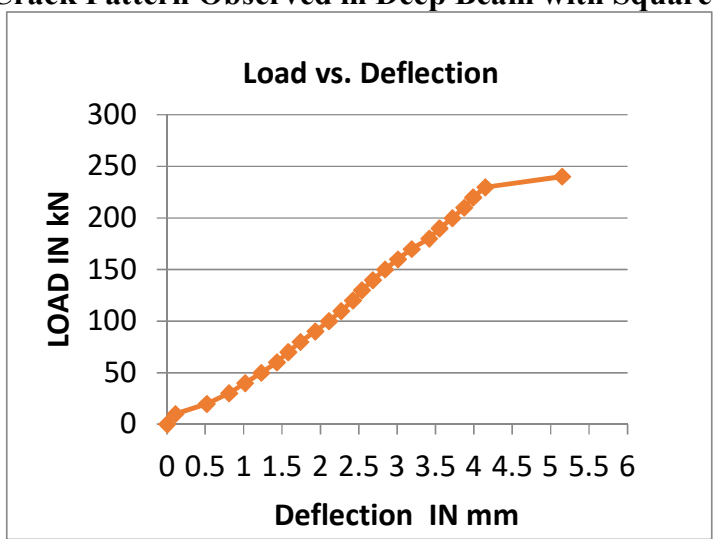

Figure 9 Load Deflection Behaviorof Deep Beam with Square Openings 


\subsubsection{Deep Beam with Square Openings}

With a deflection of $2.36 \mathrm{~mm}$, the first crack appeared under a load of $130 \mathrm{kN}$. The crack widened as the load rose, and the deep beam failed at $248 \mathrm{kN}$ with a maximum deflection of $5.84 \mathrm{~mm}$. The deep beam with circular openings failed by shear and showed shear cracks within the shear span region and no bending cracks were found.

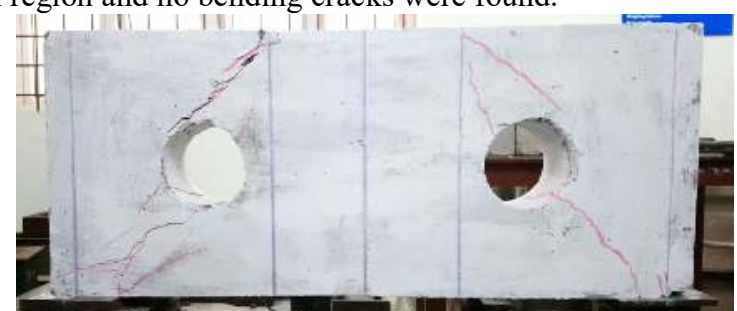

Figure 10 Crack Pattern Observed in Deep Beam with Circular Opening

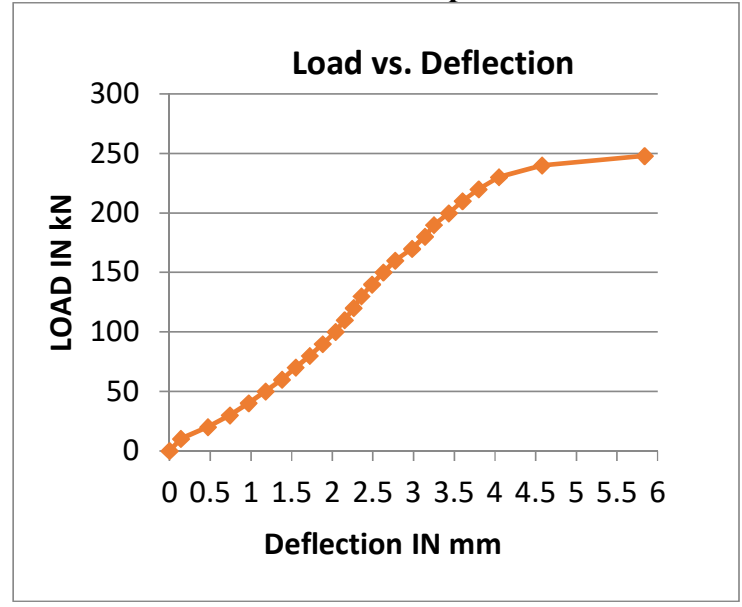

Figure 11 Load Deflection Behavior of Deep Beam with Circular Openings

\section{Conclusions}

An experimental examination of the effect of square and circular openings on the behavior of $\mathrm{RC}$ deep beams is presented in this research paper. From the findings and discussions, the following conclusions were drawn:

- The percentage decrease in the first crack load of the deep beam with square opening is $66.67 \%$ when compared with the conventional beam.

- The percentage decrease in the first crack load of the deep beam with circular opening is $51.85 \%$ while compared with the first crack load of deep beam without openings.

- The maximum load of $\mathrm{RC}$ deep beam with a square opening is reduced by 4.032 percent while compared with the maximum load ofRC deep beam with a round 
opening. Shear cracks appeared in deep beams with square and round holes due to shear failure.

\section{References}

[1] Basil Mathew, 2016, Numerical Study on FRP Strengthened RC Deep Beams with Openings, International Journal of Innovative Research in Science, Engineering and Technology, Vol. 5.

[2] Islam M R, Mansur M A and Maalej.M, 2005, Shear strengthening of RC deep beams using externally bonded FRP systems, ELSEVIER, 413-420.

[3] Mohammed Rasheed, 2016, Retrofit of Reinforced Concrete Deep Beams with Different ShearReinforcement by Using CFRP, IISTE, Vol.8.

[4] Tamer E I Maaddawy and SayedSherif, 2009,FRP composites for shear strengthening of reinforced concrete deep beams with openings, ELSEVIER, Composite structures,60-69.

[5] SiewChoo Chin ,Fadzil Mat Yahaya,DOHshuIng, AndriKusbiantoro and Wen Kai Chong 2015, Experimental Study on Shear Strengthening of RC Deep Beams with Large Openings Using CFRP, International Conference on Architecture, Structure and Civil Engineering,89-95.

[6] Zhichao Zhang, Cheng-Tzu Thomas Hsuand Jon Moren, 2004,Shear Strengthening of Reinforced Concrete Deep Beams Using Carbon Fiber Reinforced Polymer Laminates, ASCE Journal of Composites for Construction, 403-414

[7] ACI 440.2R-08 Guide for the Design and Construction of Externally Bonded FRP Systems for Strengthening Concrete Structures.

[8] IS 456: 2000, Indian Standard: Plain And Reinforced Concrete -Code Of Practice.

[9] IS 10262:2009 Indian Standard:Concrete Mix Proportioning - Guidelines

[10] D. S. Vijayan, A. Mohan, J. J. Daniel, V. Gokulnath, B. Saravanan, and P. D. Kumar, "Experimental Investigation on the Ecofriendly External Wrapping of Glass Fiber Reinforced Polymer in Concrete Columns," vol. 2021, 2021.

[11] D.S. Vijayan, A. Mohan, J. Revathy, D. Parthiban, R. Varatharajan, "Evaluation of the impact of thermal performance on various building bricks and blocks: A review", Environmental Technology \& Innovation 23 (2021) 101577, https://doi.org/10.1016/j.eti.2021.101577.

[12] R. Goplalakrishnan, A. Mohan, L. Ponrajsankar, D. S. Vijayan, "Characterisation On Toughness Property of Self- Compacting Fibre Reinforced Concrete", Journal of Environmental Protection and Ecology 21, No 6, 2153-2163 (2020). 